\title{
Avoiding Tax Obligations
}

\author{
Aflintua H. Sormin. BC *, Amir Macmud. BC ** \\ DOI: 10.29322/IJSRP.12.01.2022.p12150 \\ http://dx.doi.org/10.29322/IJSRP.12.01.2022.p12150
}

\begin{abstract}
Tax avoidance is a transaction scheme aimed at minimizing the tax burden by taking advantage of the difficulty of interpreting a country's tax regulations.

This research focuses on the habits of everyone trying not to incur costs or minimize expenses, especially in paying taxes. Both central and local taxes, in other words, the government (ic Directorate General of Taxes) and the interests of taxpayers are sometimes contradictory.

The interests of the Directorate General of Taxes and the interests of taxpayers can be seen from two sides. The first side is related to development interests. from this point of view, both parties have the same interest, namely that the public interest must be jointly developed by all components of the nation's children.

Taxpayers as members of the public also want to enjoy the availability of public service interests and public facilities provided by the government.

The government to provide for the public interest takes sources of funds from community members or taxpayers to meet the needs of the state budget.

It is the collection (ic. tax) that is contrary to the interests of the government, which aims to raise funds to better serve the public interest.

Most taxpayers always try to avoid paying taxes correctly following the applicable laws and regulations, while on the other hand, the government continues to create laws and regulations together with the parliament, state revenues from the tax sector are getting bigger.
\end{abstract}

\section{BACKGROUND OF THE PROBLEM}

$\mathrm{T}$ he Unitary State of the Republic of Indonesia is a form of state whose government system is based on the Pancasila ideology. Since the Indonesian nation was proclaimed on August 17, 1945, the nation's founders saw that the problems faced by the state were not only in the political field but for the welfare of its people.

One of the goals of the establishment of the state is the realization of a just and prosperous society. This vision of justice and people's welfare received great attention from the founders of the country. They realize that the goals and ideals of the state based on Pancasila must be able to accommodate the interests of the people. Therefore, the concept of the purpose of the state includes the welfare of its people.

Whereas for the welfare of the community, it is ordered to cooperate with the parliament to make tax regulations to collect state revenues (ic taxes) as contained in Article 23A of the 1945 Constitution.

Taxes are collected from citizens and used to finance all public interests. Taxes are a source of state income whose value is very large to be used to fulfill the public interest for the prosperity and welfare of the community. For this reason, the government and parliament make coercive tax law, and the tax paid does not have a direct impact on the payer.

The purpose of the establishment of the law on taxes is to obtain the state's income from taxes as much as possible. With the orderly rules of tax legislation that are so complete and complex, tax planning arises (Tax Lanning)

Whereas in tax planning the treatment does not violate the tax laws and regulations.

\section{THEORY BASIS}

Tax avoidance is an active resistance that comes from the taxpayer. This is done when the (Tax Assessment Letter) has not been issued. This tax avoidance is carried out to avoid the obligation to pay taxes. In the tax law, the tax rate is very varied, Corporate Income Tax is $22 \%$, VAT is currently a single rate of $10 \%$, but following the HPP Law which applies April 1, 2022, it will be $11 \%$, and in 2025 it will be $12 \%$. Meanwhile, the local tax rate for example restaurant parak is $10 \%$ of services.

Transfer pricing can be defined as a company scheme in avoiding the obligation to pay taxes or tax evasion efforts. This means that multinational companies tend to divert their company's income to other countries with relatively small tax rates.

Characteristics of taxpayers who do tax evasion can be distinguished according to taxpayer groups, ranging from large taxpayers to mediocre taxpayers. Large taxpayers tend to take advantage of their large financial capacity to hire people who are reliable and know the loopholes in the tax laws while ordinary taxpayers usually hold back on buying, using, working.

According to Aristotle, humans are Zoon Politicons or social creatures. Social beings mean needing or caring for each other and working together so that a reciprocal relationship is needed between the strong and the weak, as well as the rich and the poor. This is also in line with the ideas of the Indonesian Philosopher, Nicolaus Driyarkara (1913-1967), who argued that humans are also homo homini socius, which means that humans become friends with each other.

The idea of homo homini socius was put forward to show that in essence humans have the nature of social togetherness. On the other hand, humans are also economic creatures (homo economicus) which means that humans judge and choose things only based on personal considerations (individualists) as expressed by economic figures, Adam Smith (1723-1790) in his book An Inquiry into the Nature and Causes of the Wealth of Nations (Marwoto, et al,

With the concept of mutual need, the state is here to create a rule for collecting money from the public in a legal way, through laws and regulations made together with parliament, commonly called tax regulations. 
In developing countries, it is not easy to raise public awareness so that they voluntarily pay taxes, many factors cause people to still be reluctant to pay taxes. Or choose to evade paying taxes and not even care about taxes.

Indonesia is a developing country that carries out continuous and sustainable development that aims to improve the welfare of the people both materially and spiritually. To be able to realize this goal, the state must explore sources of funds from within the country in the form of taxes.

Tax is a mandatory contribution of its citizens (ic, rayat) to the state, either as an individual or a business entity that is coercive, based on the law, by not getting a direct reward and is used for the needs of the state for the greatest prosperity of the people.

Tax payments are a manifestation of the obligation and participation of taxpayers to participate directly and jointly in carrying out state financing and national development. Following the philosophy of tax law, paying taxes is not only an obligation but is the right of every citizen to participate and participate in state financing and national development.

\section{ANALYSIS METHOD}

There are two kinds of taxes in Indonesia, namely central taxes and local taxes. Central tax is a tax that is managed directly by the central government (Directorate General of Taxes) under the Ministry of Finance. Meanwhile, Regional Tax is a tax that is managed by the Regional Government at the Provincial and Regency/City levels.

\section{Central Tax consists of:}

1. Income Tax (PPh)

Income tax is imposed on individuals or business entities on income received or earned in a tax year. The tax includes income, such as business profits, salaries, gifts, and so on. According to the Income Tax Law, there are 3 groups of income tax subjects, including:

a. The individual and the undivided inheritance as a unit.

b. Entities consisting of Limited Liability Companies, Limited Liability Companies, and other companies, BUMN and BUMD with any name and form, Guilds, Associations, Firms, Joint Ventures, Cooperatives, Foundations or similar organizations, pension fund institutions, and other forms of business entities.

c. Permanent Establishment that is imposed by an individual who does not reside in Indonesia or Indonesia for less than 183 days in 12 months. Or a business entity that is not established or domiciled in Indonesia, but runs its business and activities in Indonesia.

\section{Value Added Tax (VAT)}

3. Sales Tax on Luxury Goods (PPnBM)

4. Stamp Duty

5. Land and Building Tax (PBB)

\section{Types of Local Taxes}

The following types of taxes are managed by the local Provincial Government:

\section{Motor Vehicle Tax}

2. Transfer Fee for Motor Vehicles

3. Motor Vehicle Fuel Tax

4. Surface Water Tax

Types of local taxes managed by the Regency/City Government, including:

-Hotel Tax,

-Restaurant or restaurant tax

-Entertainment Tax,

- Advertisement tax

Street Lighting Tax,

Tax on Non-Metal and Rock Minerals, Parking Tax,

Groundwater Tax,

Rural and Urban Land and Building Tax,

Fee for the Acquisition of Rights on Land or Buildings.

\section{TAX AVOIDANCE PRACTICES}

Tax avoidance practices carried out by taxpayers are as follows: 1. Loan money to a large nominal bank

Income Tax Law No. 36 of 2008 and Law no. 11 the Year 2020 regarding Job Creation. Requires what bank loan interest can be charged if it is related to business activities. To earn, collect and maintain income. (Article 6 paragraph 1 of the Income Tax Law)

In other words, the taxpayer borrows money from the bank with a large nominal so that the interest on the loan is getting bigger, the interest on the loan can be charged in the taxpayer's fiscal financial statements if the loan is not to increase the taxpayer's capital or increase production.

2. Giving nature and enjoyment

Giving in kind (except the provision of food and drinks for all employees) as well as reimbursement or compensation in the form of in-kind and enjoyment in certain areas may not be charged as a deductible expense.

3. Grant

The grants contained in Article 4 paragraph (3) letter a number 2 of Law No. 36 of 2008 stipulate that grant assets received by blood relatives in a straight line of one degree are excluded from the object of taxation.

Donated assets such as land and buildings given by grandfather to grandchildren are tax objects because the assets received are not in a straight line of one degree. Taxpayers like the grandfather are looking for loopholes so that they are not subject to income tax by giving donations to Mr. A who is the son of the grandfather, then the property that has legally belonged to Mr. A was given again to Mr. B who is the son of Mr. A (grandson of the grandfather).

\section{Utilization of PP Number 23 of 2018}

Entrepreneurs and SMEs who have an income of less than IDR 4.8 billion in one tax year can pay a tax of 0.5 percent of their gross turnover.

Rogue entrepreneurs can use this facility if the taxpayer has a personal and corporate business by breaking up the financial statements of all the taxpayer's businesses.

The enactment of PP No. 23 of 2018 also creates injustice, because a newly established company is certain that its business

This publication is licensed under Creative Commons Attribution CC BY.

http://dx.doi.org/10.29322/IJSRP.12.01.2022.p12150

www.ijsrp.org 
circulation is very small. However, the imposition of the tax rate is calculated from the circulation of the business which includes capital.

5. Transfer Pricing.

Transfer pricing, which is a company policy in determining the transfer price of a transaction, be it goods, services, intangible assets, or financial transactions carried out by multinational companies.

Initially, transfer pricing was a neutral transaction, and transfer pricing is a strategy or method used by multinational companies to coordinate their production and determine sales in different business segments (Heimann \& Reichelstein: 2012).

As globalization flows, the nature of business evolves from single companies to complex groups (Multinational Enterprises/MNEs) that cross national borders. The implication is that there is a need to determine standard transaction prices (transfer pricing) between companies within a group.

Regarding international transfer pricing, the principles of fairness and business practice are agreed upon. This principle states that under the same conditions, the price or profit in the exchange of goods and services between related parties should be the same as the price in the case of exchange with unrelated parties.

But later. The term transfer pricing has a negative connotation because it is considered a wetland for multinational companies to apply tax evasion practices, by transferring their income to countries with lower tax rates.

\section{Avoidance of Double Taxation.}

Double tax avoidance has the opportunity to Smuggle Taxes.

Tax authorities in many countries in the world anticipate the impact of globalization by agreeing called the Double Taxation Avoidance Agreement (P3B) or also known as a tax treaty. But even so, P3B has the opportunity for tax smuggling.

This is the way for taxpayers to make various efforts to avoid or

Reduce tax payments. This is done so that the net income obtained from transactions at the international and local levels will be smaller.

Why do taxpayers tend to avoid paying taxes?

Since the tax reform in Indonesia in 1983, Indonesia has adopted self-assessment, which means that taxpayers have been given the authority to self-calculate, self-report, and pay their taxes owed.

The principle of tax collection in Indonesia is based on justice by adhering to the principle of equality, namely that tax collection by the state must be following the ability and income of the taxpayer, in which the state may not act discriminatory against taxpayers. Thus the government can only supervise the payment of taxes by the public.

To increase public awareness about the importance of taxes, both in terms of collection and benefits, it is necessary to hold education about the importance of taxes and carry out continuous socialization, both through print and electronic media. Print media in the form of advertisements in the form of pamphlets or banners on the roadside or strategic places that provide information on tax benefits. Electronic media in the form of advertisements on television, radio, and the internet explain the importance of taxes.
With the tax reform, which is given the authority to calculate the tax owed, deposit it, and report it to the DGT, there is an opportunity for the public to avoid paying taxes.

In addition to the relatively large tax rate, there is a tendency for taxpayers to avoid paying taxes, including:

1. Psychological reasons. Income Tax $(\mathrm{PPh})$ is a tax that is directly charged to the public. when people pay taxes at the end of the year, they no longer have money to pay taxes because the income they earn has been consumed, this will certainly be burdensome.

Furthermore, psychologically, no one wants to part with their hard-earned money if at all possible.

2. Historically, most developing countries were colonies of European countries. The independence of developing countries was preceded by a struggle for independence from foreign invaders. In this struggle, politically, people were taught not to obey the law to frustrate the colonialists, one of which was not paying taxes. It is this paradigm that is still attached that taxes are a product of the colonialists.

3. Religion, in developing countries, religion plays a very important role. Some religious leaders think that taxes are a legacy of the colonial period and not paying taxes is not a sin. This provides a strong justification for a person's reluctance to pay taxes. Whereas the teachings of the Bible encourage that the right to the emperor (ic. Tax) is an obligation to be paid.

4. Lack of education about taxes, in developing countries, the level of education is quite low and there is no tax education at all. For an uneducated person, it is difficult to understand the importance of paying taxes. Neither the government nor anyone in the private sector makes any effort to explain the reasons for paying taxes to the public. Taxes are often seen as a punishment.

5. Lack of social ethics, people in developing countries also lack social ethics. The law has no significance for them. People always only think about their rights and privileges. Liability is very neglected. Based on this thinking, paying taxes as an obligation would be much more difficult to do.

6. Lack of social taboos, compliance with the law is treated as a sign of weakness and those who break the law are considered brave. Ironically, in developing countries, large numbers of people proudly claim to their peers that they pay no taxes at all.

7. Lack of prevention efforts, in developing countries, hundreds of people are imprisoned every day for petty theft. However, despite the many billions of tax evasions, very few taxpayers are imprisoned. Tax evaders do not consider that tax evasion is an act that has a criminal risk.

8. Payment transactions via cash, in a cash-based economy, hiding income is not only easy but also safe. In an economic system like this, tax evasion has a very conducive environment to thrive. Therefore, it spread very quickly.

9. Commercial incentives, if the producer or importer hides the transaction, it forces the wholesaler to do the same. Thus, retailers on the next line, have no choice but to hide the transaction. Furthermore, there is still a desire to hide transactions. In this kind of culture, honest bookkeeping is impossible. Even honest people are forced to go with the flow to be dishonest.

10. The complexity of the tax law, the Income Tax Law (UU $\mathrm{PPh}$ ) is related to commercial transactions and must cover a very wide variety of transactions so that the Income Tax Law is 
complex. This complexity provides sufficient justification for the common people to embezzle it.

11. Boring tax procedures, if tax law is complicated, it can be estimated that tax administration procedures will be even more complicated. Therefore, complicated tax procedures will encourage people to stay away from taxes for as long as possible

12. High tax rates, high rates will justify for people to avoid paying taxes. Low tax rates may not necessarily encourage people to pay taxes, but high rates are not conducive to tax compliance.

13. Tax officers are often scary for taxpayers.

14. The distrust factor. there are still some people who do not believe in the law in the field of taxation.

15. People are reluctant to pay taxes because there are still people who want to try not to pay taxes. "If you get caught, you just pay taxes. If you don't, you don't pay.

16. People's reluctance in paying taxes is partly because the practice of paying taxes has not yet become a culture.

17. The public has not complied with paying taxes due to the reason for filling out the Annual Income Tax Return (SPT)which is considered complicated

18. Tax money deposited in corruption

19. Lack of enjoyment of available public services

20. The use of tax money, the government is considered to lack transparency

The Government (ic. Head of the East Java Regional Tax Office I John Hutagaol) said that tax avoidance and tax evasion practices can eliminate tax revenues and erode the tax base that is currently needed to finance the country's needs. "Tax revenue is the main source of revenue for every country that runs its administration in a modern way and has a civilized population like Indonesia," he said in a tax talk show entitled Red and White Paying Taxes, Thursday (19/8/2021).

\section{CONCLUSION}

Tax avoidance is an effort made by taxpayers, to reduce or even eliminate tax debts that must be paid which are carried out legally, safely and do not violate the provisions in the field of taxation by way of exploit the weaknesses (grey areas) contained in the tax laws of a country.

Tax avoidance is tax avoidance by reducing taxes that are still within the limits of the provisions of tax laws and regulations and can be justified, especially through tax planning. Tax avoidance can occur in the sound of the provisions or written in the law and is in the soul of the law but is contrary to the soul of the law.

Tax avoidance is a legal action by taking advantage of loopholes in the tax rules that are often difficult to interpret.

Usually, the company carries out legal strategies or methods following the applicable laws and regulations, but this is done by utilizing ambiguous things in the law so that in this case the taxpayer takes advantage of the gaps caused by ambiguity. in tax law.

Whereas taxes are a source of state revenue, which will be used by state administrators to meet public needs such as building schools, legal houses as well as repairing roads and for the welfare of the community, state administrators are obliged to provide education to every citizen so that they voluntarily pay taxes.

Likewise, the transparency of state revenues from the tax sector must be further increased, as well as applying severe penalties for corruptors, because the money they corrupt is money collected from the people.

Thank you, hopefully useful.

Greetings

Medan, November 8, 2021

\section{REFERENCES}

[1] Prof. Mardiasmo Taxation revised edition 2011

[2] Dr. Prianto Budi. Kreston Pratama Indonesia Tax Management

[3] Denny Darusallam Tax Center

[4] Muklicine Riadi

[5] Aghnia, A. 2016, Analysis of Double Taxation Avoidance Agreement (P3b) in the System

[6] Law in Indonesia.

[7] Brotodihardjo, R. Santoso, 2008, Introduction to Tax Law, Bandung: Refika Aditama.

[8] Bryan, A.G. (1999), Black's Law Dictionary. London: West Thomas Reuters Publisher.

[9] Maghfiroh, L. 2012, The Effect of the Implementation of the Double Taxation Avoidance Agreement Between

[10] Indonesia-China Against Indonesia-China International Trade.

[11] Sony Devano and Siti Kumia R. 2006. Taxation, Concepts, Theory and Issues.

[12] Jakarta: Kencana Prenada Media Group.

[13] Suandi, Erly, 2008, Tax Law, Jakarta: Salemba Empat.

[14] Surahmat, R. (2000), Double taxation avoidance agreement: an introduction / Rachmanto

[15] Surahmat

[16] Zain, M. 2007, Tax Management (3rd Edition), Jakarta: Salemba Empat.

[17] More about this source textSource text required for additional translation information

[18] Send feedback

[19] Side panels

\section{AUTHORS}

First Author - Aflintua H. Sormin. BC. 202120211

Second Author - Amir Macmud. BC. 